\title{
The mantle source of the eastern Australian leucitites: evidence from whole rock and olivine compositions (and why the olivine compositions do matter)
}

JOSHUA J SHEA, ANTHONY W LANATI, ISRA S EZAD, SINAN ÖZAYDIN AND STEPHEN F. FOLEY

Macquarie University

Presenting Author: joshua.shea1@hdr.mq.edu.au

Eastern Australia contains over 50 mafic intraplate volcanic provinces which erupted over the last $\sim 100 \mathrm{Ma}$; the majority of these are basaltic and erupted on thin lithosphere that overlies a shallow lithosphere-asthenosphere boundary (LAB; <125 km). Leucitite provinces are rare globally, but occur in significant numbers through central New South Wales and Victoria. The leucitites are low-volume eruptions on thicker lithosphere (LAB $\sim 140 \mathrm{~km}$ ), and are temporally removed from the basaltic provinces. Some intraplate provinces lie along the Cosgrove continental hotspot track, which youngs southward from northern Queensland to Victoria. The track begins with basalts which transition to younger leucititic provinces in New South Wales and Victoria. Many of the mafic provinces, including the leucitites, are adjacent to major steps in the lithosphere base and coincide with regions of higher electrical conductivity in the lithospheric mantle; suggesting that interaction between metasomatised mantle domains and edge driven convection may generate these melts.

Here, we present new whole-rock and olivine chemistry from every major leucitite province with well-preserved olivines allowing us to delineate between signatures from volcanic processes and mantle source mineralogy. Whole-rock Mg\# (100 $\mathrm{x} \mathrm{Mg} /(\mathrm{Fe}+\mathrm{Mg}))$ values range between $69-74$ and are in equilibrium with measured olivine phenocrysts, suggesting they are mantle-derived melts. Surprisingly, olivine Ni compositions have an extraordinarily large range $(2800-5400 \mathrm{ppm})$, which occurs over a relatively restricted Fo range $(87-89)$. Although these are some of the highest $\mathrm{Ni}$ concentrations measured in olivine, whole-rock Ni compositions do not exceed 500 ppm. This suggests a substantial and varied temperature effect that increases the partition coefficient of $\mathrm{Ni}$ in olivine during eruption, rather than being a signature for a source dominated by pyroxenite. The potassic to ultrapotassic composition of the leucitites $\left(\mathrm{K}_{2} \mathrm{O} / \mathrm{Na}_{2} \mathrm{O} 2.37-6.75\right)$ and high concentrations of $\mathrm{TiO}_{2}(3.30-5.02$ wt. \%) suggest that modal metasomatism resulted in phlogopite and oxide minerals in the source.

Our new geochemical data demonstrates that the base of the lithospheric mantle is substantially metasomatized and melting these domains has led to the generation of the potassium-rich eastern Australian leucitites. 